\title{
HESSD
}

\section{Temperature and rainfall estimates for past 18000 years in Owens Valley, California with a coupled catchment-lake model}

Z. Yu ${ }^{1,2}$, W. Dong ${ }^{3}$, and P. Jiang ${ }^{4}$

${ }^{1}$ State Key Laboratory of Hydrology-Water Resources and Hydraulic Engineering, Hohai University, Nanjing, China

${ }^{2}$ Department of Geoscience, University of Nevada, Las Vegas, Las Vegas, Nevada, USA

${ }^{3}$ Department of Conservation \& Natural Resources, Nevada Division of Environmental Protection, Las Vegas, Nevada, USA

${ }^{4}$ Division of Hydrologic Sciences, Desert Research Institute, Las Vegas, Nevada, USA

Received: 22 April 2015 - Accepted: 09 June 2015 - Published: 03 July 2015

Correspondence to: Z. Yu (zhongbo.yu@unlv.edu)

Published by Copernicus Publications on behalf of the European Geosciences Union.

Temperature and rainfall estimates for past 18000 years in

Owens Valley

Z. Yu et al.

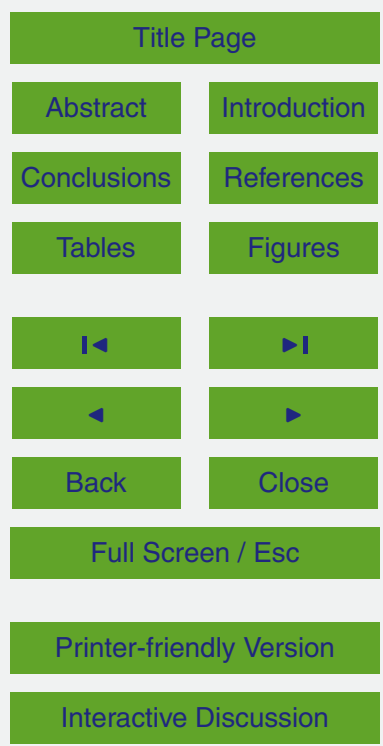

Interactive Discussion 


\section{Abstract}

Closed-basin lakes are intricately linked to the hydrological systems and are very sensitive recorders of local hydro-climatic fluctuations. Lake records in closed-basins are usually used to investigate the paleoclimate condition which is critical for understand5 ing the past and predicting the future. In this study, a physically based catchment-lake model was developed to extract quantitative paleoclimate information including temperature and rainfall over the past 18000 years (ka) from lake records in a hydrologically closed basin in the Owens River Valley, California, US. The initial model inputs were prepared based on current regional climate data, boundary conditions from the General 10 Circulation Model, and fossil proxy data. The inputs subsequently were systematically varied in order to produce the observed lake levels. In this way, a large number of possible paleoclimatic combinations can quickly narrow the possible range of paleoclimatic combinations that could have produced the paleolake level and extension. Finally, a quantitative time-series of paleoclimate information for those key times was obtained.

\section{Introduction}

The information on past climate change has been extracted from a variety of archives such as trees, ice, sediments, and corals (Anchukaitis et al., 2013; Marcott et al., 2013; Steinman et al., 2012; Viau et al., 2012). These archives can provide a qualitative interpretation of the history of Earth's climate. In past few decades, climate models emerge as an effective way to quantitatively test the hypotheses of past climate change (Kutzbach, 1987; COHMAP-Members, 1988; Street-Perrott and Harrison, 1985). However, they are not reliable at regional scale especially for variables such as precipitation (Kutzbach, 1987; Groppelli et al., 2011; Jiang et al., 2013). To overcome these shortcomings, an integrated utilization of numerical modeling and paleocliamte archives is proposed to provide quantitative paleoclimate information at region scale. Among these various paleoclimate archives, lake levels in closed basins are the most sensitive
HESSD

12, 6505-6539, 2015

Temperature and rainfall estimates for past 18000 years in

Owens Valley

Z. Yu et al.

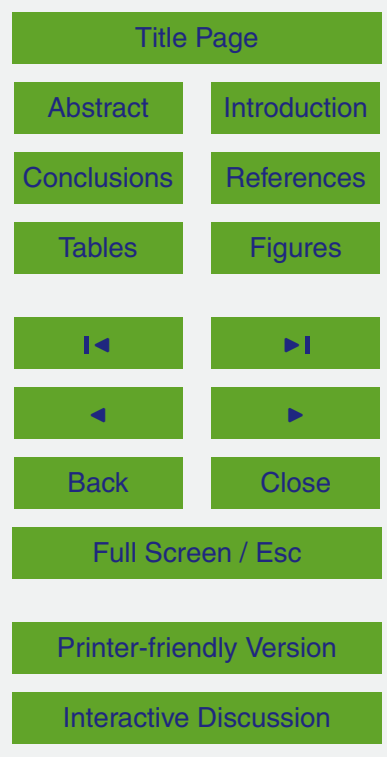


indicators of the water balance between precipitation and evapotranspiration (StreetPerrott and Harrison, 1985).

In southern Great Basin, the regional distinctive tectonic settings and geomorphic characteristics create many hydrologically closed basins that were filled with water 5 during pluvial lake periods (Smith and Street-Perrott, 1983; Street-Perrott and Harrison, 1985; Phillips, 1994; Bischoff et al., 1997; Menking et al., 1997; Lowenstein et al., 1999; Bischoff and Cummins, 2001). Most of them shrunk or dried up under the current dry and hot desert climate over this region. The evolution of lake size is determined by various climate variables such as wind velocities, relative humidity, temperature, and 10 etc. Among them, precipitation is the most important one (Smith, 1991). For instance, lakes in Owens River system, California, are termed as "natural rain gauges" (Smith and Bischoff, 1997) as they can track the changes in precipitation within the catchments they are located at. However, interpretations of climate changes based on the water level changes is generally limited to identification of wetter or drier conditions, 15 and provide little information about the specific nature of the climate change. The reason for this is that lake level in a particular basin is a complicated function of intra-basin and extra-basin climate and basin topography (Magny, 2004; Jones et al., 2001; Angel and Kunkel, 2010; Benson and Thompson, 1987). In order to extract quantitative paleoclimatic proxies from these lake records, one of the best approaches is through 20 numerical modeling.

A variety of models have been used to simulate the paleo-record of closed basin lakes in arid and semiarid areas (Kutzbach, 1980; Benson, 1981, 1986; Hostetler and Bartlein, 1990; Hostetler and Benson, 1990; Hostetler et al., 1993, 1994; Ghile et al., 2014). Physically-based lake models, which explicitly represent the physical processes governing the energy and water balances of the lake, offer a more robust way to predict climate induced changes in water volume, level, and outflow of the lakes. A suitable lake model for paleolake level studies should require a minimum of site-specific parameters (Hostetler and Giorgi, 1993). In this paper, we developed a coupled catchmentlake model and used it to quantitatively estimate paleoclimate information, especially
HESSD

$12,6505-6539,2015$

Temperature and rainfall estimates for past 18000 years in

Owens Valley

Z. Yu et al.

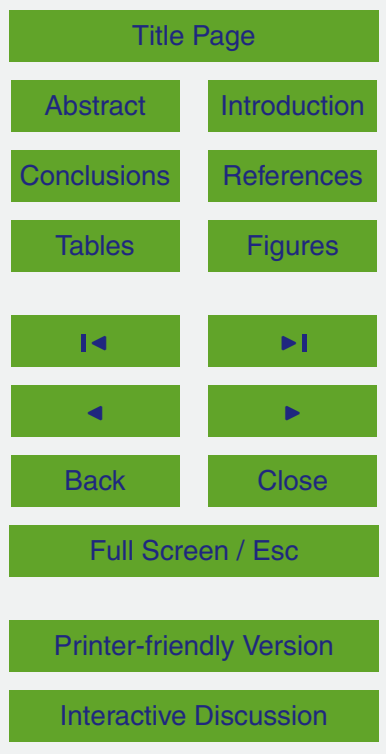


annual mean precipitation and temperature in southwestern Great Basin since the last glacial maximum (LGM). To test the hypothesis that quantitative paleo-climate variables can be obtained through numerical modeling in the closed basin area, we first derived the past lake extent from field evidence, then we conducted an inverse modeling with 5 a physically based lake model for the simulation of the derived lake extent at a specific time, and finally reconstructed the climatic conditions. Compared to the paleo-climate information derived from various archives or simulated by the climate models, the proposed method can provide quantitative estimate on temperature and precipitation at finer regional resolution.

\section{Owens River system}

The Owens River system is located at the western margins of the Great Basin. It is a hydrologically closed basin that consists of a chain of lakes including Mono Lake, Owens Lake, China Lake, Searles Lake, Panamint Lake, and Death Valley Lake (Fig. 1). The floors of all these lakes except Mono Lake are now occupied by playa lakes or salt

flats. The valley is bound on the west by the Sierra Nevada, on the northeast by the Inyo and White Moutains, and on the southeast by the Coso Range. Presently, Owens River drains an area of about $8550 \mathrm{~km}^{2}$. Due to the strong rain shadow effect, most of the runoff is derived from about $16 \%$ of the catchment area, which lies on the eastern slope of the Sierra Nevada (Lee, 1912). Modern climate in the floor of the Owens River system is semi-arid with about $15 \mathrm{~cm}$ of annual precipitation. Thus, precipitation that fell directly on the surface of the basins is an insignificant contribution to the lake water budget, which could also be true for the lakes in the paleo-Owens River system (Jannik et al., 1991). Street-Perrott and Harrison (1985) termed such lakes as "amplifier" lakes, which describe a simple relationship among basin runoff, lake evaporation, and lake area (Smith and Bischoff, 1997).

Owens Lake, at the base of high mountains, responds firstly to the increasing regional precipitation. The Owens Lake is the terminal of the Owens River, it was about
HESSD

$12,6505-6539,2015$

Temperature and rainfall estimates for past 18000 years in

Owens Valley

Z. Yu et al.

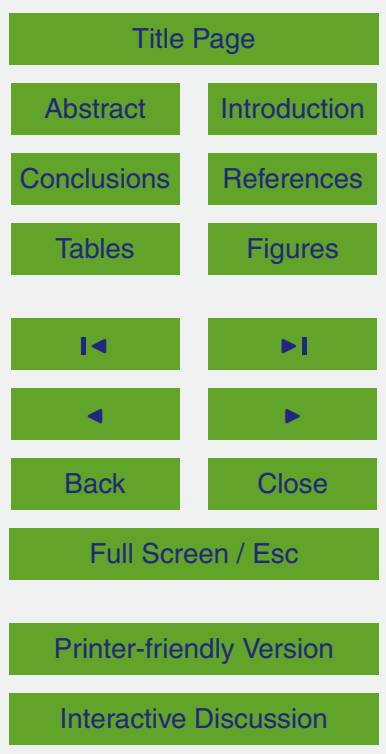


$10 \mathrm{~m}$ deep and $290 \mathrm{~km}^{2}$ in area before agricultural irrigation became extensive in 1912. All of the river's water was diverted to Los Angeles in 1912, and the lake desiccated. Searles Lake was the third in a chain of five permanent lakes receiving water from the Owens River during the late Pleistocene, and Mono Lake was separated from the 5 Owens River system to the south by a high-altitude sill in the late Wisconsin (Benson and Thompson, 1987). During the LGM, Owens Lake, China Lake, and Searles Lake overflowed and the Panamint Valley is a terminal of the Owens River hydrological system. Lake stages at Searles Lake are sensitive to climatic changes because of the storage capacities of the upper lakes in the series. Inflow to Searles Lake depends on overflow from the other lakes and therefore is first affected by a decreasing inflow in their lake system.

Studies on lacustrine outcrops, cores, and landforms have allowed the reconstruction of the past histories of lakes in the Owens River system and its downstream basins (Smith and Street-Perrott, 1983; Smith and Bischoff, 1997). The paleo lake levels are recorded by the geomorphic and sedimentary evidence including staircases of abandoned shorelines and abrupt changes of facies in sediments. Smith and Street-Perrott (1983) provide a chronology of Late Wisconsin to present lake level fluctuations for Searles Lake (Fig. 2).

Benson et al. (1997) identified two hiatuses at 2.25 and $9.2 \mathrm{~m}$ based on the ${ }^{14} \mathrm{C}$ data of Core OL84B from Owens Lake. These two hiatuses represent two desiccation events that occurred $\sim 15.3-13.5$ and $\sim 6.1-4.3 \mathrm{ka}$ (all ages used in the text of this paper are on ${ }^{14} \mathrm{C}$ time scale before present (BP)) in Owens Lake. The $\delta^{18} \mathrm{O}$ data of sediments between the two hiatuses show four abrupt dry/wet oscillations that have their correspondents in the North Atlantic region. Relatively wet intervals precede each of the dry $(-13 \%$ ) of lake carbonate (Benson, 1999). Based on the ostracode assemblage from the Owens Lake, Forester (2000) derived more details on lake level changes of the Owens Lake from 25 to $4 \mathrm{ka}$; Li et al. (2000) provided detailed information on climate

HESSD

12, 6505-6539, 2015

Temperature and rainfall estimates for past 18000 years in

Owens Valley

Z. Yu et al.

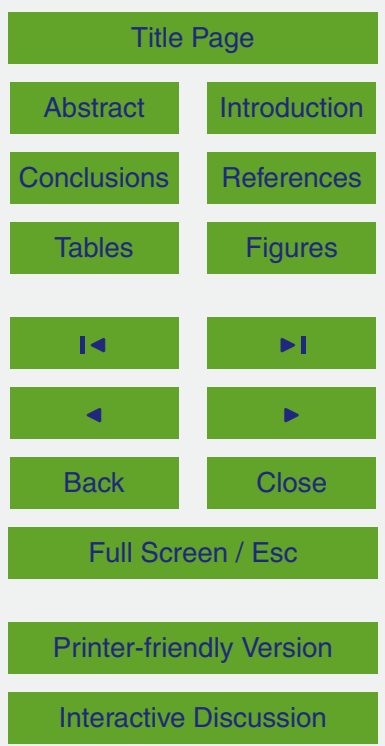


for the past 1000 years; and Benson and Paillet (2002) plotted $\delta^{18} \mathrm{O}$ with age for past 18 ka (Fig. 2).

Bacon et al. (2006) suggested that pluvial Owens Lake had dropped $45 \mathrm{~m}$ from its latest Pleistocene highstands of $1145 \mathrm{~m}$ by $11600 \mathrm{yr}$ BP. This lowstand was followed by

5 an early Holocene transgression that attained a highstand near $1135 \mathrm{~m}$ before dropping to $1120 \mathrm{~m}$ at $7860-7650 \mathrm{yr}$. The lake then lowered another $30 \mathrm{~m}$ to shallow and near desiccation levels between 6850 and $4300 \mathrm{yr}$ BP and minor lake-level rise after $4300 \mathrm{yr}$ BP, followed by alkaline and shallow conditions during the latest Holocene.

In summary, the detailed paleolake records in the Owens River system offer a good opportunity to extract quantitative paleoclimate information in the western Great Basin.

\section{Description of model and modelling strategies}

The surface area of a closed-basin lake under natural conditions is strictly dependent on the dynamic equilibrium between precipitation and evapotranspiration over its entire catchment (Halley, 1714). Any changes in this equilibrium result in a change in termi15 nal lake depth, which directly influences its area, and the cumulative lake area in the drainage basin (Benson and Paillet, 1989). The mean annual water balance of a lake is governed by the equation (Street-Perrott and Harrison, 1985):

$\Delta V=A_{\mathrm{L}}\left(P_{\mathrm{L}}-E_{\mathrm{L}}\right)+(R-D)+\left(G_{1}-G_{\mathrm{O}}\right)$

where $\Delta \mathrm{V}$ is the net change in volume of the lake, $P_{\mathrm{L}}$ is precipitation on the lake, $E_{\mathrm{L}}$ is evaporation from the lake, $A_{\mathrm{L}}$ is the area of the lake, $R$ and $D$ are runoff from the catchment and the surface discharge from the lake, respectively, and $G_{1}$ and $G_{O}$ are groundwater flows into and out of the lake respectively. For a closed basin lake, $G_{1}$ and $G_{O}$ can be assumed negligible, and $D$ is zero, so Eq. (1) reduces to the following form for equilibrium conditions:

$25 R=A_{\mathrm{L}}\left(E_{\mathrm{L}}-P_{\mathrm{L}}\right)$.
HESSD

12, 6505-6539, 2015

Temperature and rainfall estimates for past 18000 years in

Owens Valley

Z. Yu et al.

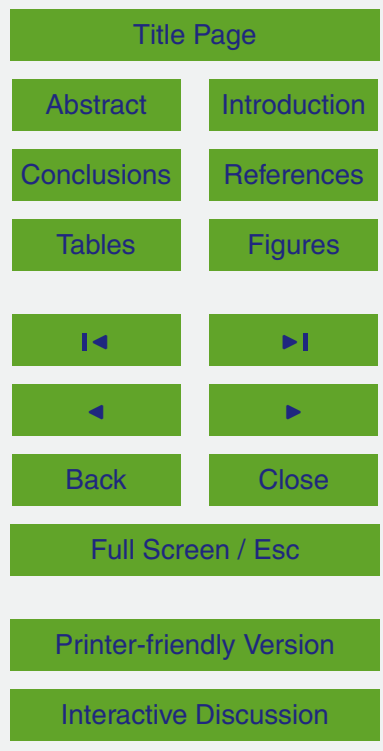


where $A_{\mathrm{B}}$ represents area of the catchment, $P_{\mathrm{B}}$ is the precipitation over the catchment, and $E_{\mathrm{B}}$ is the evapotranspiration over the catchment, then we have

$5 \quad A_{\mathrm{B}}\left(P_{\mathrm{B}}-E_{\mathrm{B}}\right)=A_{\mathrm{L}}\left(E_{\mathrm{L}}-P_{\mathrm{L}}\right)$.

This simple expression shows that the equilibrium area of a closed lake under natural conditions is strictly dependent on the precipitation and evaporation over its catchment and water surface. In the Owens River system, based on paleolake records, values for $A_{\mathrm{L}}$ and $A_{\mathrm{B}}$ for those paleolakes can be measured quite accurately using a digital 10 elevation model (DEM). Remaining components in Eq. (4) are precipitation and evaporation over the drainage basin. The evaporation mainly depends on temperature, thus the purpose for this paper is to develop a coupled catchment-lake model to resolve these two unknown variables in the Eq. (4).

The evaporation value depends on many climatic factors including solar radiation, 15 temperature, wind speed, and cloud cover. With the exception of temperature, other relevant factors are difficult to reconstruct from geologic data. Many studies assume that paleo-values for the evaporation can be satisfactorily estimated from empirical relationships between modern data on evaporation and air temperature. However, a change in evaporation rates could result from higher wind velocities, higher relative humidities and lower solar radiation values, and greater amounts of precipitation on the lake surface (Smith and Street-Perrott, 1983). Therefore, it is desirable to have a model that considers all of these factors. Hostetler and Bartlein (1990) developed one-dimensional surface energy-balance lake model, where the vertical heat transfer was simulated by eddy diffusion and convective mixing. Several studies using this model have successfully simulated the modern and paleolake level change both in humid and arid regions (Vassiljev, 1997; Hostetler and Benson, 1990; Hostetler et al., 1994). Orndorff (1994) developed a surface hydrologic model (OSHM) that has been successfully applied to

Temperature and rainfall estimates for past 18000 years in

Owens Valley

Z. Yu et al.

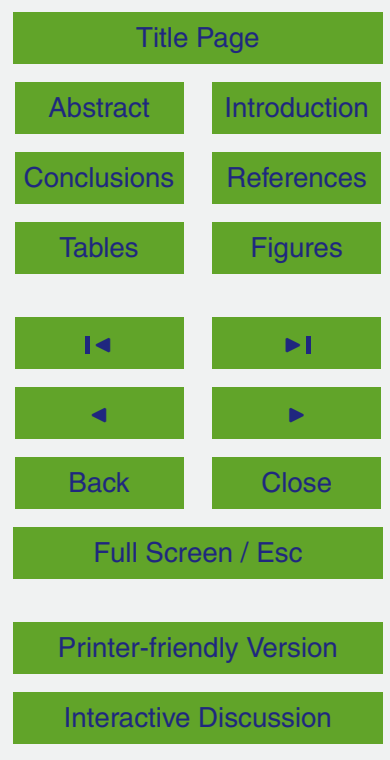


the Owens River system to test the proxy estimates of the LGM against the paleolake records. The OSHM has three modules: the snow module that computes mean monthly snowfall, snowmelt, snowpack, ice accumulation, ice transport, and icemelt for each grid cell based on the input of temperature, precipitation, and elevation of that 5 cell, the runoff module that calculates mean annual runoff from available water (rain, snowmelt, and icemelt), and the lake module computes lake extent from the results of basin-wide mean annual runoff calculated by the runoff module and lake evaporation. In the OSHM, empirical relationships between modern data on evaporation and air temperature were used to calculate the evaporation for the pluvial lakes in the Owens River 10 system during the LGM, which may not represent the actual situation as discussed above. In this study, the lake module in the OSHM was modified with the addition of Hostetler's lake model and used to simulate evaporation over the lake surface.

The paleoclimatic evaluation strategy is first to model lake extent under current climatic conditions with the coupled catchment-lake model developed in this study. The 15 input parameters under current climatic conditions are then systematically varied in order to reconstruct lake extent based on lake records under paleoclimatic conditions. The modeling strategy is essentially an inverse approach to inferring paleoclimatic conditions based on past lake extent. The advantage of this modeling strategy is that a large number of possible paleoclimatic combinations can be quickly narrowed to 20 a possible range of temperature/precipitation combinations that could have produced a particular paleolake extent.

A simulation on lake extent begins with dry closed basins In order to prevent water from overflowing into previously considered basins, basins are taken into account in order from the highest to lowest active outlet elevation, which means that the Monon Lake is first full and overflows to Owens Lake, then the Owens Lake is full and overflows to China Lake, then China Lake is full and overflows to Sears Lake, the Sears Lake is full and overflows to Panamant Lake, finally the Panamant Lake is full and overflows to Death Valley Lake. Each basin's runoff volume from its catchment is added to the current lake volume at each time step. The lake volume is compared to the basin

HESSD

$12,6505-6539,2015$

Temperature and rainfall estimates for past 18000 years in

Owens Valley

Z. Yu et al.

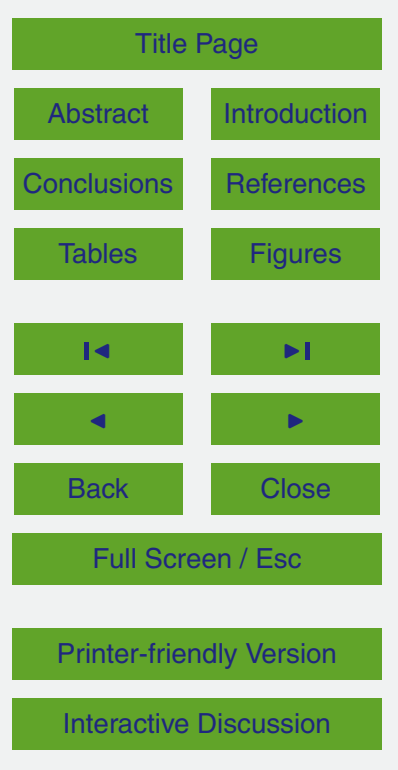


threshold volume, which corresponds to a lake level equal to the controlling elevation of the lowest basin outlet. Overflow occurs into the basin on the other side of the outlet when the lake volume exceeds the threshold volume. The model also checks for lake merging during overflow, which occurs when two lakes with a common active outlet overflow, thus inundating the active outlet. If two lakes merge, the downstream basin becomes a part of the upstream basin, and the remaining outlets of both basins are sorted to determine the new active outlet for the complex basin (Orndorff, 1994). Lake evaporation is then calculated using the eddy diffusion and convective mixing (Hostetler and Bartlein, 1990), and the lake level is adjusted accordingly. The simulation runs in one year time step until the cumulative lake volume equilibrates or the run time exceeds a specified end time. Benson and Paillet (1989) state that "the proper gage of lake response to change in the hydrologic balance is neither lake depth (level) nor lake volume but instead lake surface area", thus this study focused on lake surface area for a comparison of simulated lake extent and derived lake extent based on geologic 15 evidence.

\section{Calibration of catchment-lake model}

The catchment-lake model used in this study was developed by coupling a distribution hydrology model (Orndorff, 1994) and an energy-balance lake model (Hostetler and Bartlein, 1990). Both of these two models were independently calibrated with observed data (Orndorff, 1994; Hostetler and Bartlein, 1990; Hostetler, 1991), thus they are valid when use them independently. However, the catchment-lake model developed for this study has to be calibrated before applying it to simulate paleolake levels. The Mono Lake is presently only lake with standing water in Owens Valley. The three major streams (Rush, Lee Vining, and Mill Creeks) that delivery water to Mono Lake istics of Mono Lake and Owens Lake is similar Observed data including climate data, hydrological data and lake level data are available for the Mono Lake drainage basin

HESSD

12, 6505-6539, 2015

Temperature and rainfall estimates for past 18000 years in

Owens Valley

Z. Yu et al.

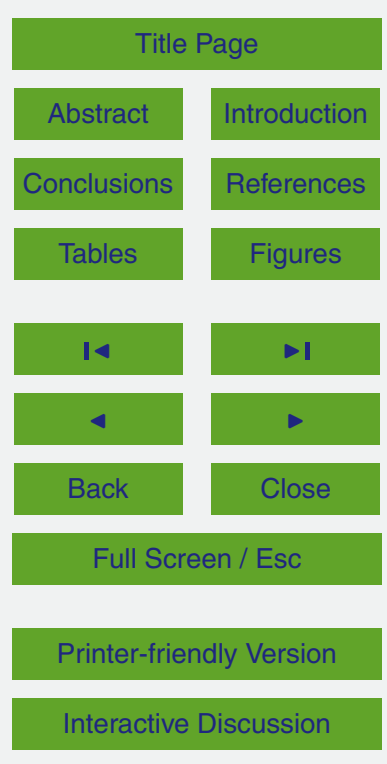


since 1857 (Mono-Basin-Environmental-Impact-Report, 1993). The data on measured temperature profiles and lake evaporation are also available for some periods of time (Maclntyre et al., 1999). The calibration was done with input data including modern precipitation and temperature matrix data for the Mono Lake drainage basin from the LCM 5 (Stamm, 1992), solar radiation data from the Desert Rock, vapor pressure, wind speed and cloudiness data from stations close to the Mono Lake. The simulated monthly runoff for the Mono Lake drainage basin is compatible with the observed (Fig. 3) and the annual runoff is about $1 \%$ less than the observed. The simulated lake surface area is $224 \mathrm{~km}^{2}$ that is $1.8 \%$ less than the average of the observed lake surface area 10 from 1940 to 1989 (Mono-Basin-Environmental-Impact-Report, 1993). The lake temperature profile simulated by the model agreed very well with measured temperature profile (Fig. 4a). Furthermore, the simulated evaporation also compares well with the observed evaporation data through the grant pan, but slight higher than the evaporation estimated from water budget method (Fig. 4b). These comparisons indicated that the overall ability of the coupled catchment-lake model developed here to reproduce observed basin-wide mean annual runoff, mean lake surface area, temperature profile and evaporation of lake water in modern Mono Lake drainage basin.

\section{Input parameters}

A number of input parameters are required for the coupled catchment-lake model. 20 Coarse grid cell $(5 \mathrm{~km} \times 5 \mathrm{~km})$ used in the OSHM missed some small snow cover and stream networks, and did a poor job representing some basin shapes (Orndorff, 1994). In this study, the fine resolution $(1 \mathrm{~km} \times 1 \mathrm{~km})$ data was used to obtain better results. The topographic data used in this model is from the global 30 arcsec elevation data set (GTOPO30) (https://lta.cr.usgs.gov/GTOPO30). The GTOPO30 has a horizontal grid spacing of 30 arcsec (approximately $1 \mathrm{~km}$ ). Observed solar radiation, cloud cover, wind speed, atmospheric pressure from near weather stations, and modern monthly temperature and precipitation matrix from local climate models (Stamm, 1992) that are based
HESSD

12, 6505-6539, 2015

Temperature and rainfall estimates for past 18000 years in

Owens Valley

Z. Yu et al.

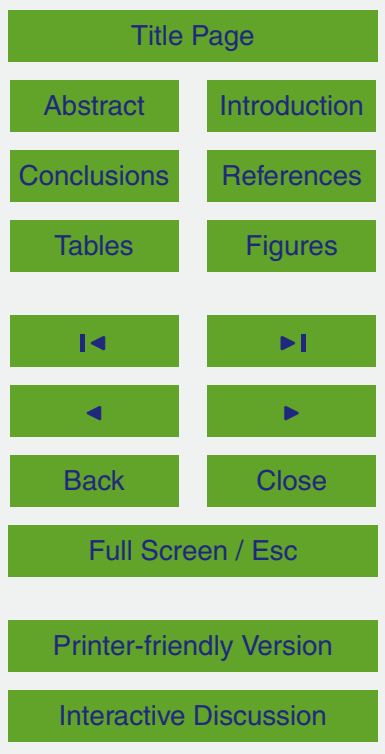


on boundary conditions including terrain, wind field, and radiation balance were used to drive the newly developed catchment-lake model and to reproduce the historical lake level of the Owens Lake. Precipitation and temperature matrix data at 18, 15, 12, 9 , and 6 ka were prepared based on the proxy data in Table 1 by applying the appropri5 ate perturbation (simple additive change for temperature, and multiplicative change for precipitation) to the modern monthly precipitation and temperature matrix data from the LCM. For example, climate at the LGM might be hypothesized to be $5^{\circ}$ colder and $50 \%$ wetter than the present based on proxy data in Table 1 . The input climate matrix at the LGM could be prepared for temperature by subtracting $5^{\circ} \mathrm{C}$ from the modern tempera10 ture matrix, and for precipitation by multipling 1.5 to modern precipitation matrix. Other climate parameters including cloud cover (Fig. 5a), solar radiation (Fig. 5b and c), and wind speed (Fig. 6) were from historic records for modern conditions, and from the Community Climate Model (CCM0) (Kutzbach and Guetter, 1986) and the results of paleoclimate simulation of North America (Bartlein et al., 1998) for paleoclimatic sim15 ulation. However, the single monthly value for these parameters was used for whole area. The reason for this is: first, there is no such final resolution data available for these parameters in the study area; second, previous study indicated that precipitation and temperature are two primary factors controlling the glacial extent (Plummer and Phillips, 2003).

20 As most observation data are available only for Owens Lake and Searles Lake, the comparison between the simulated results and the observation data in this study focused on these two lakes.

\section{Results}

\subsection{Simulation on modern lakes}

25 Mean annual runoff, computed for modern climate from the runoff module is input to the lake model to simulate modern lake extent in the Owens Valley. The resulting lakes
HESSD

$12,6505-6539,2015$

Temperature and rainfall estimates for past 18000 years in

Owens Valley

Z. Yu et al.

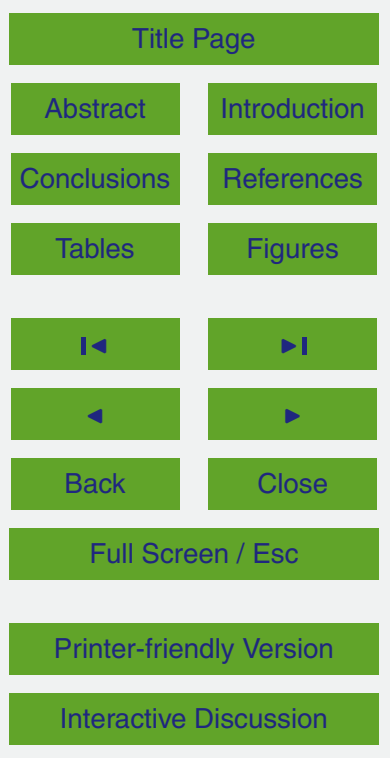

(i) 
along with hillshed and stream network that were derived from the DEM are shown in Fig. 7a. The lake system converges in 80 years. There is no lake mergence occurring. The results from modern simulation accurately portray Mono Lake, Lake Crowley (in the Long Valley basin), Black Lake (in Adobe Basin), and Owens Lake. Simulated 5 Mono Lake has a surface area of $224 \mathrm{~km}^{2}$ that is about $2 \%$ less as compared to the average $228 \mathrm{~km}^{2}$ of the observed lake surface area from 1940 to 1989 (Mono-BasinEnvironmental-Impact-Report, 1993). Simulated Owens Lake has a surface area of $302 \mathrm{~km}^{2}$ that is about $4 \%$ more as compared to an observed pre-diversion surface area of $290 \mathrm{~km}^{2}$ (Smith and Street-Perrott, 1983).

\subsection{Simulations on lakes at Last Glacial Maximum}

Simulations on lakes at the LGM in the Owens Valley were done with modern temperature and precipitation matrices perturbed based on proxy-based LGM temperature and precipitation departures (Table 1), and other climate parameters including solar radiation, cloud cover, and wind speed from CCMO (Kutzbach and Guetter, 1986) and 5 the results of paleoclimate simulation of North America (Bartlein et al., 1998) that were fixed. By varying combinations of temperature and precipitation with appropriate perturbation until the derived lake extent at the LGM from field evidence was reproduced, the final combination with temperature $5.5^{\circ} \mathrm{C}$ cooler and 1.25 times precipitation of modern climate conditions was obtained. Simulated final lake extents with hillshed and stream network are shown in Fig. 7f. Owens Lake overflows, and has a lake surface area of $692 \mathrm{~km}^{2}$. China Lake and Searles Lake coalesce and have an area of $949 \mathrm{~km}^{2}$. Searles Lake also overflows and a small lake with an area of $144 \mathrm{~km}^{2}$ was formed in Panamint Valley. These results are very compatible with observed lake extent in Owens Valley at the LGM reported by Smith and Street-Perrott (1983).
HESSD

12, 6505-6539, 2015

Temperature and rainfall estimates for past 18000 years in

Owens Valley

Z. Yu et al.

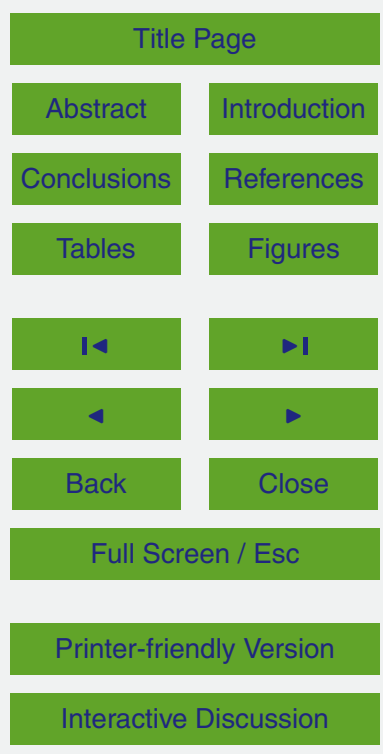




\subsection{Simulation on lakes at $15 \mathrm{ka}$}

The techniques used to prepare input data for simulations on lakes in Owens Valley at $15 \mathrm{ka}$ are same as them for the LGM. Based on ${ }^{14} \mathrm{C}$ and sedimentary features, Benson et al. (1997) reported a desiccation event would occur for Owens Lake at $515 \mathrm{ka}$. Because Owens Lake is an upstream lake of Searles Lake, and Searles Lake received most of its inflow from the overflow of Owens Lake, Searles Lake could also desiccate at $15 \mathrm{ka}$. This is supported by the field evidence that the Searles Lake was at its low water level with an elevation at $510 \mathrm{~m}$. Therefore, the simulation on lake extent in Owens Valley at $15 \mathrm{ka}$ is to find a combination of precipitation and temperature that can create a dry Owens Lake and Searles Lake. After multiple runs, a combination with temperature $1.8^{\circ} \mathrm{C}$ cooler and precipitation $20 \%$ less than modern climate condition could produce a dry Owens Lake and Searles Lake (Fig. 7e). The results from this simulation also indicated that a significant decline in the level of Mono Lake. This is consistent with possible hiatuses in cores from the Mono Lake basin (Newton, 1991) 15 and major declines in the levels of Mono Lake and Lake Lahontan (Benson et al., 1998, 1996).

\subsection{Simulation on lakes at 12 ka}

The $\delta^{18} \mathrm{O}$ data from Core OL84B drilled in Owens Lake indicated the lowest values of $\delta^{18} \mathrm{O}$ at $12 \mathrm{ka}$ for the last $15 \mathrm{ka}$ (Fig. 2) (Benson et al., 1997). This represents highest 20 ratio of overflow to inflow into Owens Lake, which implied that Searles Lake probably also received its highest inflow for the last $15 \mathrm{ka}$. The field evidence indicated that the lake level of Searles Lake started to increase at $12 \mathrm{ka}$ and reach its highest level at 11 ka (Fig. 2) (Smith and Street-Perrott, 1983). It can be expected that the overflow from Searles Lake might finally reach its highest, and the largest lake might be formed in 25 Panamint Valley in the last $18 \mathrm{ka}$. Based on multiple runs, a combination of temperature $4.5^{\circ} \mathrm{C}$ cooler and 1.8 times precipitation of modern climate conditions could reproduce
HESSD

$12,6505-6539,2015$

Temperature and rainfall estimates for past 18000 years in

Owens Valley

Z. Yu et al.

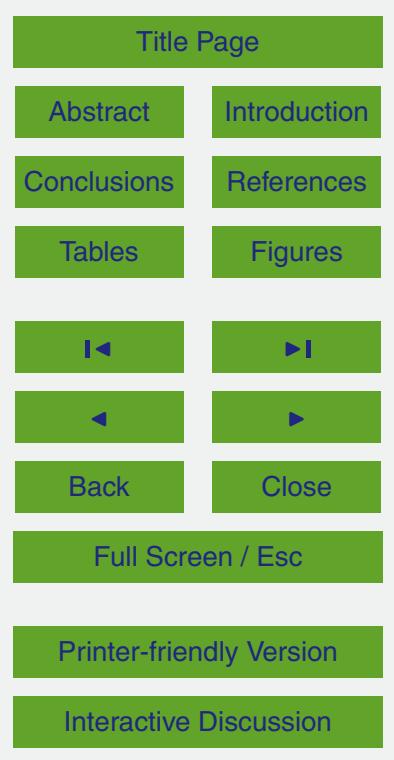


a lake system with the highest lake level in Panamint Valley (Fig. 7d) since the LGM. However, the lake level of Panamint Lake was still not high enough for overflow.

\subsection{Simulation on lakes at 9 ka}

$\delta^{18} \mathrm{O}$ values of Owens Lake at $9 \mathrm{ka}$ are around $27 \%$ indicating Owens Lake at its 5 hydrological closure (Benson et al., 1996). A dry event was recognized based on the presence of prismatic cracking that suggests the existence of a soil formed during subaerial exposure of lake sediments at about 9 ka (Benson et al., 1997). In meantime, Searles Lake was at its lowest water level since the LGM (Smith and Street-Perrott, 1983). A combination of temperature $0.5^{\circ} \mathrm{C}$ warmer and 1.2 times precipitation of modern climate conditions could reproduce a lake system in Owens Valley at 9 ka (Fig. 7c).

\subsection{Simulation on lakes at $6 \mathrm{ka}$}

Owens Lake was at its second desiccation event at 6.1-4.3 ka (Benson et al., 1997), and Searles Lake was at its water level about same as today (Smith and Street-Perrott, 1983), thus the lakes in Owens Valley at 6 ka might have shallower water stand than them under modern climatic conditions. Based on this evidence, a combination of temperature $1.2^{\circ} \mathrm{C}$ warmer and 0.9 times precipitation of modern climate conditions could produce a lake system in Owens Valley at $6 \mathrm{ka}$ (Fig. 7b).

\section{Sensitivity analysis}

Sensitivity analysis was only performed for the simulation of lakes in Owens Valley 20 at the LGM (18 ka). Based on the proxy data at the LGM in Table 1, a combination of the lowest temperature $\left(7.5^{\circ} \mathrm{C}\right.$ cooler than modern temperature) and the maximum precipitation (2.40 times modern precipitation) was used to prepare the input data for simulation on lake extent. The results from simulation based on this combination indicate that all basins including Death Valley in Owens River system are full of water,

Temperature and rainfall estimates for past 18000 years in

Owens Valley

Z. Yu et al.

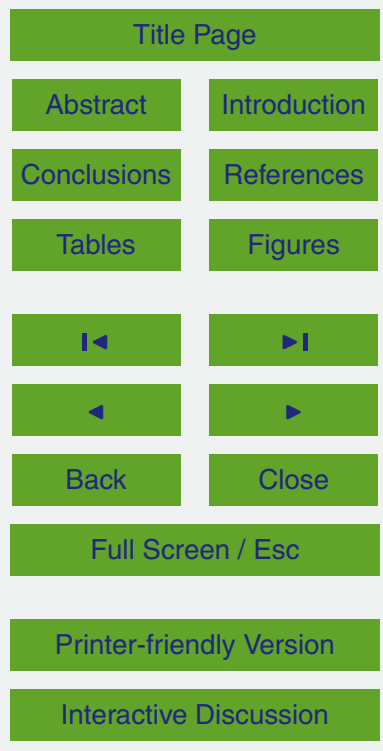


which is not case in the last $18 \mathrm{ka}$. Another combination of the highest temperature $\left(3.0^{\circ} \mathrm{C}\right.$ cooler than modern temperature) and the lowest precipitation (1.2 times modern precipitation) was used to simulate lake extent in Owens Valley. The results from this simulation indicate that Searles Lake is not full and no lake was formed in Panamint

5 Valley. The results from these two extreme cases of the combination are against to geological evidences. First, Panamint Lake did not overflow, and there is no full lake formed in Death Valley in the last $18 \mathrm{ka}$ (Smith and Street-Perrott, 1983); second, Mono Lake was separated from the Owens River system to the south by a high-altitude sill in the late Wisconsin (Benson and Thompson, 1987); third, Searles Lake was full and over10 flowed into Panamint Valley where a small lake was formed at the LGM (Smith and Street-Perrott, 1983). Therefore, the coupled catchment-lake model developed in this study is very sensitive to a change of both temperature and precipitation, and it can be easily used to infer paleoclimatic conditions based on past lake extent.

\section{Discussion}

15 The coupled catchment-lake model developed in this study has several advantages for paleoclimatic interpretation of paleolake extent. By using physically based models to find the climatic conditions that could produce a particular lake extent at specific time, a quantitative estimate on temperature and precipitation against field evidences was obtained. This approach allows direct consideration of the effects of changes in both precipitation and temperature, as well as numerous climate variables including cloud cover, solar radiation, and wind speed. Simulated lake surface areas and elevations of lake surface for major lakes in Owens Valley in the last $18 \mathrm{ka}$ are listed in Table 2. The combinations of temperature (Fig. 8a) and precipitation (Fig. 8b) that could produce observed lake extent in Owens Valley in the last $18 \mathrm{ka}$ were obtained from the simulations above. We also plotted reconstructed temperature and precipitation based on pollen in Owens Lake core OL84B in Fig. 8. Simulated combination of temperature and precipitation at the LGM $(18 \mathrm{ka})$ is $5.5^{\circ} \mathrm{C}$ cooler and 1.25 times of modern climate

\section{HESSD}

$12,6505-6539,2015$

Temperature and rainfall estimates for past 18000 years in

Owens Valley

Z. Yu et al.

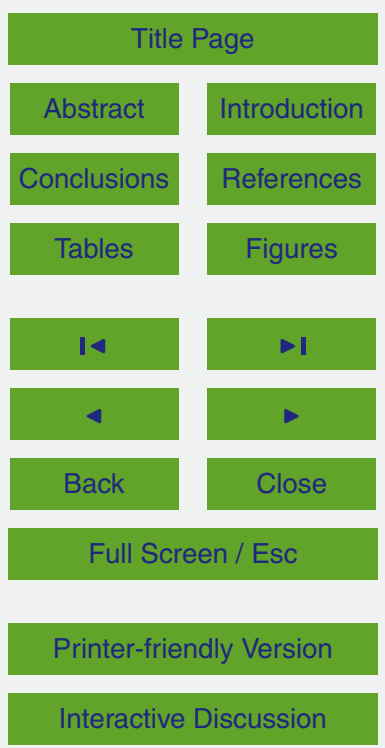


conditions. This result is close to a proxy data (Merrill and Péwé, 1977) in Table 1, but different from other proxy data in Table 1. This could be a result that the proxy-based estimates of LGM climate are representative of the area in which the fossil assemblage or glacial feature was studied. A mixed conifer forest from Kings Canyon that 5 includes red fir, western juniper, incense cedar, sugar pine, ponderosa pine, California nutmeg, and single-needle pinon pine (Cole, 1983) indicated a colder than today with near-modern precipitation levels in the southern Sierra Nevada at $18 \mathrm{ka}$. The $9.2 \mathrm{~m}$ hiatus found in Owens Lake core OL84B was dated at 15.5 to $13.5 \mathrm{ka}$ (Benson et al., 1997). Our simulation indicated lake extent at $15 \mathrm{ka}$ is the smallest in the last $18 \mathrm{ka}$.

10 The combination of precipitation and temperature produced this smallest lake extent is the lowest precipitation in the last $18 \mathrm{ka}$, and about $1.8^{\circ} \mathrm{C}$ cooler than modern temperature. The lake extent at $12 \mathrm{ka}$ in Owens Valley is largest in the last $18 \mathrm{ka}$. Simulated combination of precipitation and temperature at $12 \mathrm{ka}$ is $4.5^{\circ} \mathrm{C}$ cooler and 1.8 times of modern climate conditions. This result is consistent with the pollen data from the core OL84B (Fig. 8a, b) (Mensing, 2001). The pollen data indicated that a mean annual precipitation of $308-370 \mathrm{~mm}$ and a $>80 \%$ increase in effective moisture, and 4 to $5{ }^{\circ} \mathrm{C}$ cooler than the present mean temperature in Owens Valley start from $13.5 \mathrm{ka}$. A very wet climate in the western Great Basin at this time is also supported by the $\delta^{18} \mathrm{O}$ data from Owens Lake (Benson et al., 1996) and Mono Lake (Benson et al., 1998), and ages of tufa from Searles Lake (Lin et al., 1998) and Lake Lahontan (Benson, 1993) that indicate high lake stands from 14 to $13.5 \mathrm{ka}$. However, the climate in Sierra Nevada shifted from cool, wet conditions to possibly a more seasonal climate with cool, wet winters and warmer summers (Mensing, 2001; Smith and Anderson, 1992), but still wetter and cooler than today (Spaulding, 1983) after $12 \mathrm{ka}$. Simulated lake extent in Owens Valley at $9 \mathrm{ka}$ indicated a significantly decrease in lake extent from $12 \mathrm{ka}$. The last deglaciation was interrupted by a worldwide cooling event, the Younger Dryas (YD) from 11 to $10 \mathrm{ka}$. Studies from western North America have identified late-glacial climatic oscillations roughly synchronous with the YD interval (Stuiver et al., 1995). The pollen data from the core OL84B indicates a series of abrupt climatic oscillations between 10.8 to

HESSD

$12,6505-6539,2015$

Temperature and rainfall estimates for past 18000 years in

Owens Valley

Z. Yu et al.

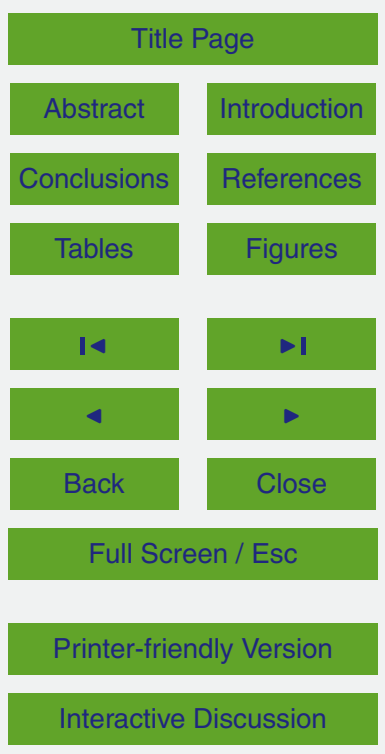


$9.5 \mathrm{ka}$, but is not sufficient to clearly define the YD for direct comparison with other sites (Mensing, 2001). Summer insolation reached a maximum between 9 to $8 \mathrm{ka}$, resulting in higher summer temperatures and probably increased seasonality (Grigg and Whitlock, 1998). Low lake levels and the increased dominance of desert shrubs indicate the 5 beginning of warm, dry Holocene conditions. The results from our simulations indicate $0.5^{\circ} \mathrm{C}$ warmer and 1.2 times of modern climate conditions could produce observed lake extent at $9 \mathrm{ka}$, which is generally agreement with high isolation and increased desert shrubs. Second hiatus found in the core OL84B indicates that Owens Lake was probably dry at $6 \mathrm{ka}$ (Benson et al., 1997), and quantitative analysis of the pollen record from 10 Sierra Nevada suggests temperatures $1.4-2.1{ }^{\circ} \mathrm{C}$ warmer than today (Adam and West, 1983). The lake level of Searles Lake was also low at 6 ka (Smith and Street-Perrott, 1983). Simulated lake extent with a combination of temperature $1.2^{\circ} \mathrm{C}$ warmer and 0.9 times precipitation of modern climate conditions is consistent with geologic evidences.

The climate in Owens Valley after $6 \mathrm{ka}$ is probably similar to modern climate condi15 tions. However, a slightly increase in precipitation and decrease in temperature could happen, because the historic lake level of Owens Lake is higher than it at 6 ka. An increased frequency of modern extreme storm events in Mojave River watershed in late Holocene was concluded based on lake deposits in the Silver Lake playa, CA (Enzel et al., 1989). The relatively high lake level of Searles Lake from 5 to $3 \mathrm{ka}$ could be a result of an increased frequency of modern extreme storm events and summer monsoon circulation (Bush, 2001).

\section{Conclusions and future work}

The coupled catchment-lake model developed in this study is capable of accurately simulating lake extent as a function of modern climate and paleoclimate. The purpose for this model is used to quantitatively estimate paleoclimate, especially annual precipitation and temperature against field evidence in a catchement-lake watershed hydrologic system. The simulations on lake extent at 18, 15, 12, 9, $6 \mathrm{ka}$, and modern
HESSD

12, 6505-6539, 2015

Temperature and rainfall estimates for past 18000 years in

Owens Valley

Z. Yu et al.

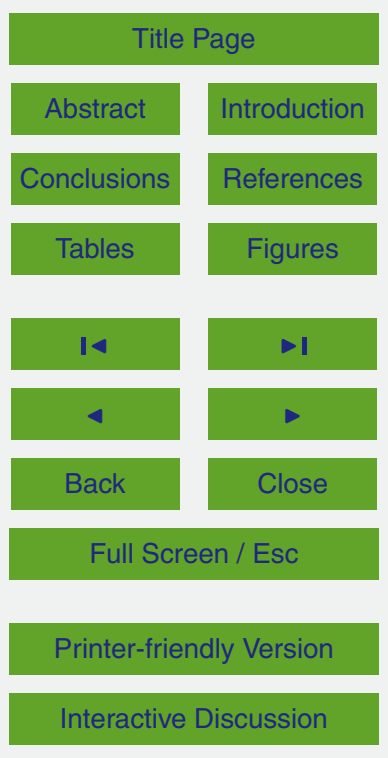


climate conditions are very compatible with observed or derived data. The annual precipitation and temperature of Owens Valley for these times are generally in agreement with the proxy data that are derived from Owens Valley and the places near Owens Valley. The accuracy of our quantitative estimates in paleotemperature and paleopre5 cipitation in Owens Valley is completely dependent on the accuracy of the field observations, especially the elevation of paleo-shorelines and their chronology for the lakes. Therefore, numeric values for the temperature and precipitation at 18, 15, 12, 9, and $6 \mathrm{ka}$ are only effective for the geologic evidences used this study. However, these numeric values of paleotemperature and paleoprecipitation can be adjusted based on 10 new geologic evidence. The two advantages of the coupled catchment-lake model are: (1) based on the proxy data, the possible range of temperature/precipitation combinations that could produce a particular paleolake extent can be easily obtained by narrowing a large number of possible paleoclimatic combinations, (2) the model developed in this study is a physically based model that requires a minimum of site-specific 15 parameters (Hostetler and Giorgi, 1993), thus it can be applied in any lakes if input parameters are available.

Simulations performed in this study did not consider that the seasonal distribution of precipitation and temperature in the last $18 \mathrm{ka}$ might be different from modern climatic conditions. The reason for this is that we seldom have information on the seasonal distribution of precipitation and temperature in the past. However, the lake levels of the Mediterranean region were significantly affected by the seasonal distribution of temperature (Prentice et al., 1992). Therefore, it is very important to consider the seasonal distribution of paleoclimate into the simulation on the paleolake extent in Owens Valley with accumulation of more data on seasonal distribution of paleoprecipitation and paleotemperature. Besides, an initially dry lake was assumed for the simulation, which is not true for most situations. Thus, the simulation could be improved by running the model continuously a high lake level at $18 \mathrm{ka}$ to a historic lake level. A time-series of temperature and precipitation from the continuous simulation is more useful than the discrete results in this study.

\section{HESSD}

12, 6505-6539, 2015

Temperature and rainfall estimates for past 18000 years in

Owens Valley

Z. Yu et al.

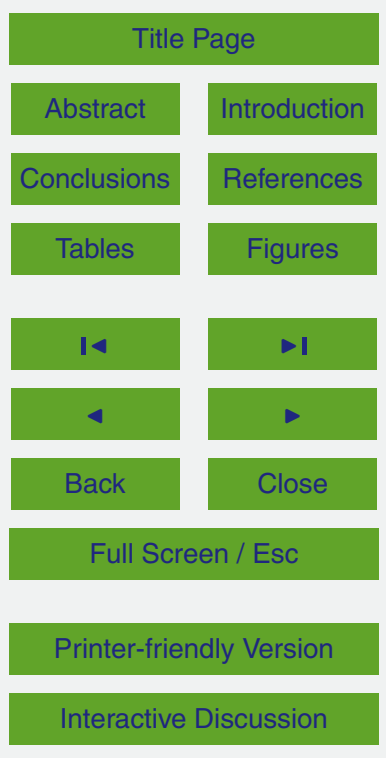


Acknowledgements. This project was funded by the Department of Energy under Sponsored Project (DE-RP08-OONV13813). The authors wish to acknowledge S. W. Hostetler for providing us the source code of his lake model. Many thanks to K. M. Menking for her assistance on running the Hostetler's lake model. The third author was funded by the support of the Sulo and

5 Aileen Maki Endowment. The authors acknowledge that the views herein are that of the authors only and does not necessary reflect the review of the funding agencies and the organizations they are affiliated to.

\section{References}

Adam, D. P. and West, G. J.: Temperature and precipitation estimates through the last glacial 10 cycle from Clear Lake, California, pollen data, Science, 219, 168-170, 1983.

Anchukaitis, K. J., D’Arrigo, R. D., Andreu-Hayles, L., Frank, D., Verstege, A., Curtis, A., Buckley, B. M., Jacoby, G. C., and Cook, E. R.: Tree-ring-reconstructed summer temperatures from Northwestern North America during the last nine centuries, J. Climate, 26, 3001-3012, 2013.

15 Angel, J. R. and Kunkel, K. E.: The response of Great Lakes water levels to future climate scenarios with an emphasis on Lake Michigan-Huron, J. Great Lakes Res., 36, 51-58, 2010.

Bacon, S. N., Burke, R. M., Pezzopane, S. K., and Jayko, A. S.: Last glacial maximum and Holocene lake levels of Owens Lake, eastern California, USA, Quaternary Sci. Rev., 25, 1264-1282, 2006.

Bartlein, P. J., Anderson, K. H., Anderson, P., Edwards, M., Mock, C., Thompson, R. S., Webb, R. S., Webb III, T., and Whitlock, C.: Paleoclimate simulations for North America over the past 21000 years: features of the simulated climate and comparisons with paleoenvironmental data, Quaternary Sci. Rev., 17, 549-585, 1998.

Benson, L. V.: Paleoclimatic significance of lake-level fluctuations in the Lahontan Basin, Quaternary Res., 16, 390-403, 1981.

Benson, L. V.: Factors affecting $14 \mathrm{C}$ ages of lacustrine carbonates: timing and duration of the last highstand lake in the Lahontan Basin, Quaternary Res., 39, 163-174, 1993.

Benson, L. V. and Paillet, F.: The use of total lake-surface area as an indicator of climatic change: examples from the Lahontan Basin, Quaternary Res., 32, 262-275, 1989.

\section{HESSD}

$12,6505-6539,2015$

Temperature and rainfall estimates for past 18000 years in

Owens Valley

Z. Yu et al.

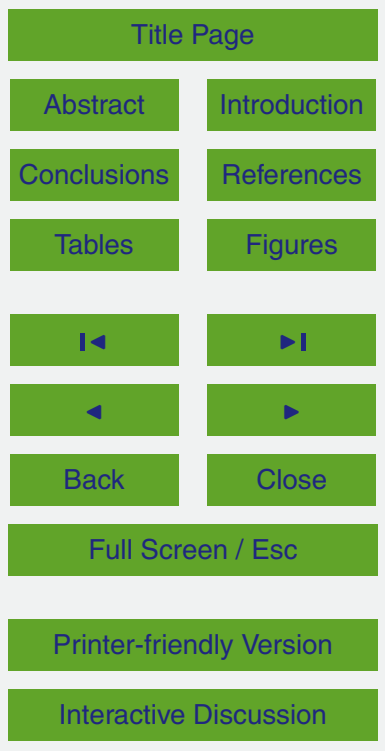


Benson, L. V. and Paillet, F.: HIBAL: a hydrologic-isotopic-balance model for application to paleolake systems, Quaternary Sci. Rev., 21, 1521-1539, 2002.

Benson, L. V. and Thompson, R.: Lake-level variation in the Lahontan Basin for the past 50000 years, Quaternary Res., 28, 69-85, 1987.

5 Benson, L. V., Burdett, J. W., Kashgarian, M., Lund, S., Phillips, F., and Rye, R. O.: Climatic and hydrologic oscillations in the Owens Lake Basin and adjacent Sierra Nevada, California, Science, 746-749, 1996.

Benson, L. V., Burdett, J., Lund, S., Kashgarian, M., and Mensing, S.: Nearly synchronous climate change in the Northern Hemisphere during the last glacial termination, Nature, 388, 263-265, 1997.

Benson, L. V.: The sensitivity of evaporation rate to climate change: results of an energybalance approach, US Department of the Interior, Geological Survey, Denver, Colorado, USA, 1986.

Benson, L. V., Currey, D. R., Dorn, R. I., Lajoie, K. R., Oviatt, C. G., Robinson, S. W., Smith, G. I., 15 and Stine, S.: Chronology of expansion and contraction of four Great Basin lake systems during the past 35000 years, Palaeogeogr. Palaeocl., 78, 241-286, 1990.

Benson, L. V., Lund, S. P., Burdett, J. W., Kashgarian, M., Rose, T. P., Smoot, J. P., and Schwartz, M.: Correlation of late-Pleistocene lake-level oscillations in Mono Lake, California, with North Atlantic climate events, Quaternary Res., 49, 1-10, 1998.

20 Betancourt, J. L.: Late quaternary biogeography of the Colorado Plateau, in: Packrat Middens: The Last 40000 years of Biotic Change, edited by: Betancourt, J. L., Van Devender, T. R., and Martin, P. S., The University of Arizona Press, Tucson, 259-292, 1990.

Bischoff, J. L. and Cummins, K.: Wisconsin glaciation of the Sierra Nevada (79000$15000 \mathrm{yr}$ BP) as recorded by rock flour in sediments of Owens Lake, California, Quaternary 25 Res., 55, 14-24, 2001.

Bischoff, J. L., Menking, K. M., Fitts, J. P., and Fitzpatrick, J. A.: Climatic oscillations 10000 $155000 \mathrm{yr} \mathrm{BP}$ at Owens Lake, California reflected in glacial rock flour abundance and lake salinity in core OL-92, Quaternary Res., 48, 313-325, 1997.

Bush, A. B. G.: Pacific sea surface temperature forcing dominates orbital forcing of the early Holocene monsoon, Quaternary Res., 55, 25-32, 2001.

COHMAP-Members: Climatic changes of the last 18000 years: observations and model simulations, Science, 241, 1043-1052, 1988.
HESSD

12, 6505-6539, 2015

Temperature and rainfall estimates for past 18000 years in

Owens Valley

Z. Yu et al.

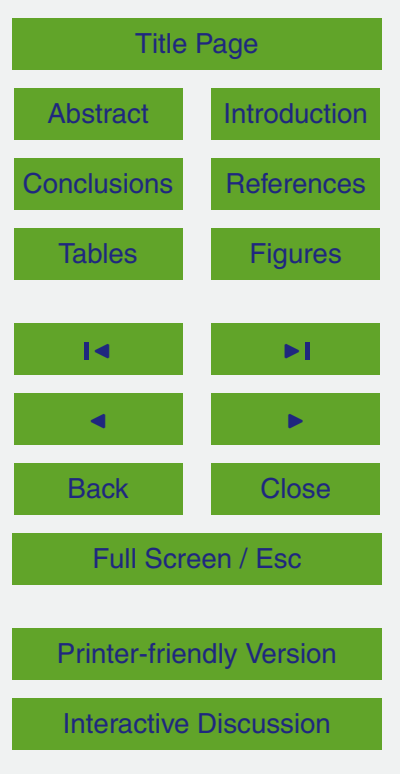

6524 
Cole, K. L.: Late Pleistocene vegetation of Kings Canyon, Sierra Nevada, California, Quaternary Res., 19, 117-129, 1983.

Cole, K. L.: Reconstruction of past desert vegetation along the Colorado River using packrat middens, Palaeogeogr. Palaeocl., 76, 349-366, 1990.

5 Dohrenwend, J. C.: Nivation landforms in the western Great Basin and their paleoclimatic significance, Quaternary Res., 22, 275-288, 1984.

Enzel, Y., Cayan, D. R., Anderson, R. Y., and Wells, S. G.: Atmospheric circulation during Holocene lake stands in the Mojave Desert: evidence of regional climate change, Nature, 341, 44-47, 1989.

10 Forester, R. M.: An ostracode record of Holocene climate change from Owens Lake, California, in: Impacts of Climate Change on Landscapes of the Eastern Sierra Nevada and Western Great Basin, edited by: Jayko, A. S. and Miller, C. I., US Geol. Surv. Open-File Rept 01-202, US Geological Survey, 7-8, 2000

Ghile, Y., Moody, P., and Brown, C.: Paleo-reconstructed net basin supply scenarios and their 15 effect on lake levels in the upper great lakes, Climatic Change, 127, 305-319, 2014.

Grigg, L. D. and Whitlock, C.: Late-glacial vegetation and climate change in western Oregon, Quaternary Res., 49, 287-298, 1998.

Groppelli, B., Bocchiola, D., and Rosso, R.: Spatial downscaling of precipitation from GCMs for climate change projections using random cascades: a case study in Italy, Water Resour.

$20 \quad$ Res., 47, W03519, doi:10.1029/2010WR009437, 2011.

Halley, E.: A Short Account of the Cause of the Saltness of the Ocean, and of the Several Lakes That Emit no Rivers; With a Proposal, by Help Thereof, to Discover the Age of the World, Produced before the Royal-Society by Edmund Halley, RS Secr, Philos. Trans., 29, 296-300, 1714.

Hostetler, S.: Modeling the late-Pleistocene paleohydrology of the Great Basin, in: Proceedings of the US Geological Survey global change research forum, edited by: Kelmelis, J. and Snow, K., US Geological Survey Circular, Herndon, Virginia, 1-90, 1991.

Hostetler, S. and Bartlein, P.: Simulation of lake evaporation with application to modeling lake level variations of Harney-Malheur Lake, Oregon, Water Resour. Res., 26, 2603-2612, 1990.

30 Hostetler, S. and Benson, L. V.: Paleoclimatic implications of the high stand of Lake Lahontan derived from models of evaporation and lake level, Clim. Dynam., 4, 207-217, 1990.

HESSD

12, 6505-6539, 2015

Temperature and rainfall estimates for past 18000 years in

Owens Valley

Z. Yu et al.

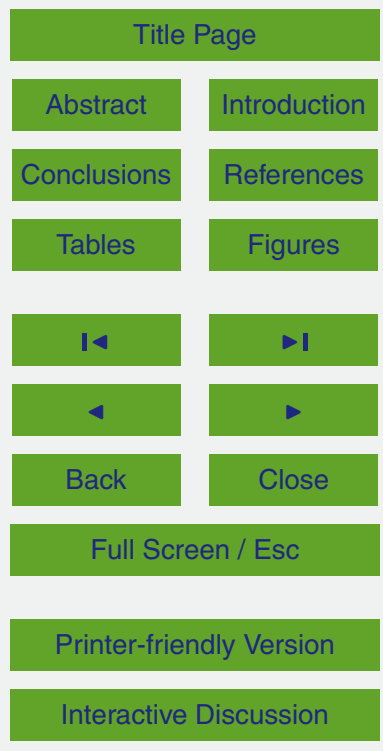


Hostetler, S. and Giorgi, F.: Use of output from high-resolution atmospheric models in landscape-scale hydrologic models: an assessment, Water Resour. Res., 29, 1685-1695, 1993.

Hostetler, S., Bates, G., and Giorgi, F.: Interactive coupling of a lake thermal model with a regional climate model, J. Geophys. Res., 98, 5045-5057, 1993.

Hostetler, S., Giorgi, F., Bates, G., and Bartlein, P.: Lake-atmosphere feedbacks associated with paleolakes Bonneville and Lahontan, Science, 263, 665-668, 1994.

Jannik, N. O., Phillips, F. M., Smith, G. I., and Elmore, D.: A $36 \mathrm{Cl}$ chronology of lacustrine sedimentation in the Pleistocene Owens River system, Geol. Soc. Am. Bull., 103, 11461159, 1991.

Jiang, P., Gautam, M. R., Zhu, J., and Yu, Z.: How well do the GCMs/RCMs capture the multiscale temporal variability of precipitation in the Southwestern United States?, J. Hydrol., 479, 75-85, 2013.

Jones, R., McMahon, T., and Bowler, J.: Modelling historical lake levels and recent climate change at three closed lakes, Western Victoria, Australia (c. 1840-1990), J. Hydrol., 246, 159-180, 2001.

Kutzbach, J. E.: Estimates of past climate at Paleolake Chad, North Africa, based on a hydrological and energy-balance model, Quaternary Res., 14, 210-223, 1980.

Kutzbach, J. E.: Model simulations of the climatic patterns during the deglaciation of North America, in: North America and Adjacent Oceans During the Last Deglaciation, edited by: Ruddiman, W. F. and Wright, J. H. E., Geological Society of America, Boulder, Colorado, 425-446, 1987.

Kutzbach, J. E. and Guetter, P. J.: The influence of changing orbital parameters and surface boundary conditions on climate simulations for the past 18000 years, J. Atmos. Sci., 43, 1726-1759, 1986.

Leffler, P. M. and Cochran, G. F.: Utilizing the historical climate record to construct an analogue of past (wetter) climatic regimes in the southwest Great Basin, in: Proceedings of the Topical Meeting on Nuclear Waste Isolation in the Unsaturated Zone, American Nuclear Society, Inc., La Grange Park, Illinois, 73-77, 1989.

30 Li, H.-C., Bischoff, J. L., Ku, T.-L., Lund, S. P., and Stott, L. D.: Climate variability in East-Central California during the past 1000 years reflected by high-resolution geochemical and isotopic records from Owens Lake sediments, Quaternary Res., 54, 189-197, 2000.
HESSD

12, 6505-6539, 2015

Temperature and rainfall estimates for past 18000 years in

Owens Valley

Z. Yu et al.

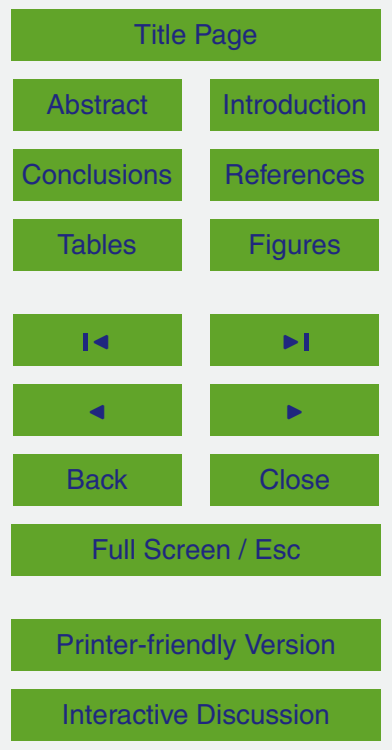


Lin, J. C., Broecker, W. S., Hemming, S. R., Hajdas, I., Anderson, R. F., Smith, G. I., Kelley, M., and Bonani, G.: A reassessment of U-Th and $14 \mathrm{C}$ ages for late-glacial high-frequency hydrological events at Searles Lake, California, Quaternary Res., 49, 11-23, 1998.

Lowenstein, T. K., Li, J., Brown, C., Roberts, S. M., Ku, T.-L., Luo, S., and Yang, W.: 200 ky paleoclimate record from Death Valley salt core, Geology, 27, 3-6, 1999.

Maclntyre, S., Flynn, K. M., Jellison, R., and Romero, J. R.: Boundary mixing and nutrient fluxes in Mono Lake, California, Limnol. Oceanogr., 44, 512-529, 1999.

Magny, M.: Holocene climate variability as reflected by mid-European lake-level fluctuations and its probable impact on prehistoric human settlements, Quatern. Int., 113, 65-79, 2004.

10 Marcott, S. A., Shakun, J. D., Clark, P. U., and Mix, A. C.: A reconstruction of regional and global temperature for the past 11300 years, Science, 339, 1198-1201, 2013.

Menking, K. M., Bischoff, J. L., Fitzpatrick, J. A., Burdette, J. W., and Rye, R. O.: Climatic/hydrologic oscillations since $155,000 \mathrm{yr} B P$ at Owens Lake, California, reflected in abundance and stable isotope composition of sediment carbonate, Quaternary Res., 48, 58-68, 1997.

Mensing, S. A.: Late-glacial and early Holocene vegetation and climate change near Owens Lake, eastern California, Quaternary Res., 55, 57-65, 2001.

Merrill, R. K. and Péwé, T. L.: Late Cenozoic Geology of the White Mountains, Arizona, 1, Ariz. Bur. Geol. and Miner. Technol., University of Arizona, USA, 1977.

20 Mifflin, M. D. and Wheat, M. M.: Pluvial Lakes and Estimated Pluvial Climates of Nevada, Mackay School of Mines, University of Nevada, Reno, USA, 1979.

Mono-Basin-Environmental-Impact-Report: Final environmental impact report for the review of Mono Basin water rights of the city of Los Angeles, California State Water Resources Control Board, Sacramento, 1993.

Newton, M.: Holocene stratigraphy and magnetostratigraphy of Owens and Mono Lakes, eastern California, PhD thesis, University of Southern California, University of Southern California, USA, 1991.

Orndorff, R. L.: Development of a surface hydrologic model and its application to modern and last glacial conditions within the Great Basin, Kent State University, Ohio, USA, 1994.

30 Phillips, F. M.: Environmental tracers for water movement in desert soils of the American Southwest, Soil. Sci. Soc. Am. J., 58, 15-24, 1994.

HESSD

$12,6505-6539,2015$

Temperature and rainfall estimates for past 18000 years in

Owens Valley

Z. Yu et al.

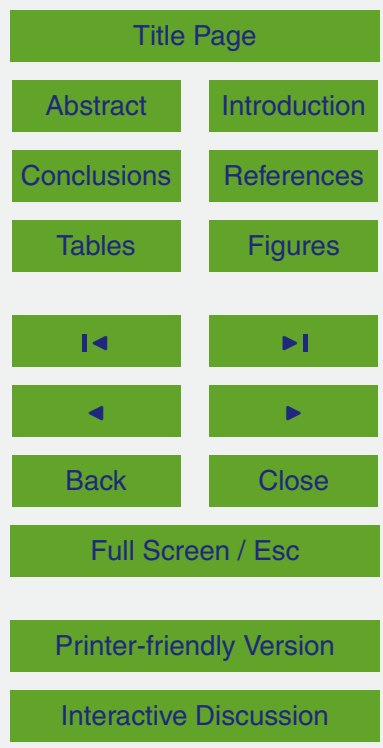


Plummer, M. A. and Phillips, F. M.: A 2-D numerical model of snow/ice energy balance and ice flow for paleoclimatic interpretation of glacial geomorphic features, Quaternary Sci. Rev., 22, 1389-1406, 2003.

Prentice, I. C., Guiot, J., and Harrison, S. P.: Mediterranean vegetation, lake levels and palaeoclimate at the Last Glacial Maximum, Nature, 360, 658-660, 1992.

Smith, G. I.: Continental paleoclimatic records and their significance, in: Quaternary Nonglacial Geology: Conterminous US, edited by: Morrison, R. B., The Geological Society of America, Boulder, Colorado, USA, 35-41, 1991.

Smith, G. I. and Bischoff, J. L.: Core OL-92 from Owens Lake: project rationale, geologic setting, drilling procedures, and summary, Geol. S. Am. S., 317, 1-8, 1997.

Smith, G. I. and Street-Perrott, F. A.: Pluvial lakes of the western United States, in: Latequaternary environments of the United States, Univeristy of Minnesota Press, Minneapolis, Minesota, 190-212, 1983.

Smith, S. J. and Anderson, R. S.: Late Wisconsin paleoecologic record from Swamp Lake,

15 Yosemite National Park, California, Quaternary Res., 38, 91-102, 1992.

Spaulding, W. G.: Vegetation and climates of the last 45,000 years in the vicinity of the Nevada Test Site, south-central Nevada, US Geological Survey, Washington, D.C., 1983.

Spaulding, W. G. and Graumlich, L. J.: The last pluvial climatic episodes in the deserts of southwestern North America, Nature, 320, 441-444, 1986.

Stamm, J. F.: Modeling local paleoclimates and validation in the southwest United States, Oak Ridge Inst. for Science and Education, Kent State University, TN, USA, 1992.

Steinman, B. A., Abbott, M. B., Mann, M. E., Stansell, N. D., and Finney, B. P.: 1500 year quantitative reconstruction of winter precipitation in the Pacific Northwest, P. Natl. Acad. Sci. USA, 109, 11619-11623, 2012.

Street-Perrott, F. A. and Harrison, S. P.: Lake levels and climate reconstruction, in: Paleoclimate Analysis and Modeling, edited by: Hecht, A. D., John Wiley and Sons, New York, 291-340, 1985.

Stuiver, M., Grootes, P. M., and Braziunas, T. F.: The GISP2 $\delta^{18} \mathrm{O}$ climate record of the past 16,500 years and the role of the sun, ocean, and volcanoes, Quaternary Res., 44, 341-354, 1995.

Thompson, R. S., Whitlock, C., Bartlein, P., Harrison, S., and Spaulding, W.: Climatic changes in the western United States since 18,000 yr BP, in: Global Climates Since the Last Glacial Maximum, edited by: Wright, H. E., Kutzbach, J. E., Webb III, T., Ruddiman, W. F., Street-
HESSD

12, 6505-6539, 2015

Temperature and rainfall estimates for past 18000 years in

Owens Valley

Z. Yu et al.

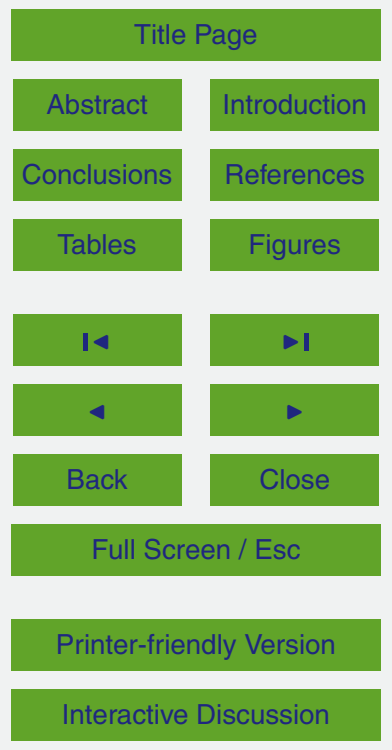

6528 
Perrott, F. A., and Bartlein, P. J., Univerisity of Minnesota Press, Minneapolis, USA, 468-513, 1993.

Thompson, R. S., Anderson, K. H., and Bartlein, P. J.: Quantitative paleoclimatic reconstructions from late Pleistocene plant macrofossils of the Yucca Mountain region, US Geological Survey Open-File Report 99-338, US Geological Survey, Denver, Colorado, USA, 1999.

Vassiljev, J.: Simulating the Palaeorecord of Northern European Lakes Using a Coupled LakeCatchment Model, Lund University, Lund, Sweden, 1997.

Viau, A., Ladd, M., and Gajewski, K.: The climate of North America during the past 2000 years reconstructed from pollen data, Global Planet. Change, 84, 75-83, 2012.

Temperature and rainfall estimates for past 18000 years in

Owens Valley

Z. Yu et al.

Title Page 
Temperature and

Table 1. Proxy data in the southwest US in the last $18 \mathrm{ka}$.

\begin{tabular}{|c|c|c|c|}
\hline Time & Temperature $\left({ }^{\circ} \mathrm{C}\right)$ & Precipitation (\%) & Source \\
\hline $\begin{array}{l}\text { Late } \\
\text { Wisconsin }\end{array}$ & $\begin{array}{l}-6.25 \text { annual } \\
-3.0 \text { annual } \\
-5.5 \text { annual } \\
-6.5 \text { annual } \\
-6.0 \text { summer } \\
-6.7 \text { annual } \\
+1.0 \text { winter, }-1.0 \text { summer } \\
-3.0 \text { Jan, }-3.0 \text { Jul } \\
-5.5 \text { to }-4.9 \text { annual }\end{array}$ & $\begin{array}{l}+37 \mathrm{~cm} \text { winter } \\
+68 \% \text { annual } \\
+27.5 \% \text { annual } \\
+65 \% \text { winter, }-45 \% \text { summer } \\
\text { Summer precipitation } 10 \% \text { of annual } \\
+32 \% \text { annual } \\
+57 \% \text { winter, }+56 \% \text { summer } \\
+19 \mathrm{~mm} \text { Jan, }-31 \mathrm{~mm} \text { Jul } \\
1.4 \text { to } 1.7 \times \text { model annual }\end{array}$ & $\begin{array}{l}\text { Dohrenwend (1984) } \\
\text { Mifflin and Wheat (1979) } \\
\text { Merrill and Pewe (1977) } \\
\text { Spaulding (1985) } \\
\text { Betancourt (1990) } \\
\text { Cole (1990) } \\
\text { Leffler and Cochran (1989) } \\
\text { Spaulding and Graumlich (1986) } \\
\text { Thompson et al. (1999) }\end{array}$ \\
\hline $18 \mathrm{ka}$ & $\begin{array}{l}-3.29 \text { annual } \\
-3.17 \text { Jan, }-3.01 \mathrm{Jul}\end{array}$ & $\begin{array}{l}-0.29 \mathrm{~mm} \text { day }^{-1} \text { annual } \\
+0.25 \mathrm{~mm}^{-1} \text { day }^{-1} \text { Jan, }-0.84 \mathrm{~mm} \text { day }^{-1} \mathrm{Jul}\end{array}$ & Thompson et al. (1993) \\
\hline $\begin{array}{l}20.5 \text { to } 18 \mathrm{ka} \\
14 \text { to } 11.5 \mathrm{ka}\end{array}$ & $\begin{array}{l}-7.5 \text { annual } \\
-6.7 \text { annual }\end{array}$ & $\begin{array}{l}2.40 x \\
2.58 x\end{array}$ & $\begin{array}{l}\text { Thompson et al. (1999) } \\
\text { Thompson et al. (1999) }\end{array}$ \\
\hline $12 \mathrm{ka}$ & $\begin{array}{l}-2.52 \text { annual } \\
-3.01 \text { Jan, }-0.63 \mathrm{Jul}\end{array}$ & $\begin{array}{l}-0.18 \mathrm{~mm} \text { day }^{-1} \text { annual } \\
-0.27 \mathrm{~mm}_{\text {day }}{ }^{-1} \text { Jan, }-0.15 \mathrm{~mm} \text { day }^{-1} \mathrm{Jul}\end{array}$ & Thompson et al. (1993) \\
\hline $9 \mathrm{ka}$ & $\begin{array}{l}+0.43 \text { annual } \\
-0.09 \text { Jan, }+2.15 \text { Jul }\end{array}$ & $\begin{array}{l}+0.30 \mathrm{~mm} \text { day }^{-1} \text { annual } \\
+0.80 \mathrm{~mm}^{-1} \text { day }^{-1} \text { Jan, }-0.27 \mathrm{~mm} \text { day }^{-1} \mathrm{Jul}\end{array}$ & Thompson et al. (1993) \\
\hline $6 \mathrm{ka}$ & $\begin{array}{l}+0.69 \text { annual } \\
+0.30 \text { Jan, }+0.68 \text { Jul }\end{array}$ & $\begin{array}{l}-0.03 \mathrm{~mm} \text { day }^{-1} \text { annual } \\
-0.16 \mathrm{~mm} \text { day }^{-1} \text { Jan, }+0.07 \mathrm{~mm} \mathrm{day}^{-1} \mathrm{Jul}\end{array}$ & Thompson et al. (1993) \\
\hline
\end{tabular}

rainfall estimates for

past 18000 years in

Owens Valley

Z. Yu et al.

Title Page

Abstract

Introduction

Conclusions

References

Tables

Figures

14

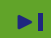

4

Back

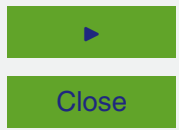

Full Screen / Esc

Printer-friendly Version

Interactive Discussion 
Table 2. Simulated lake extent and elevation of lake levels in Owens Valley in the last $18 \mathrm{ka}$.

\begin{tabular}{lcccrrrrr}
\hline $\begin{array}{l}\text { Age } \\
(\mathrm{ka})\end{array}$ & \multicolumn{2}{c}{ Mono Lake } & \multicolumn{2}{c}{ Owens Lake } & \multicolumn{2}{c}{ Searles Lake } & \multicolumn{2}{c}{ Panamint Lake } \\
& Elevation $(\mathrm{m})$ & Area $\left(\mathrm{km}^{2}\right)$ & Elevation $(\mathrm{m})$ & Area $\left(\mathrm{km}^{2}\right)$ & Elevation $(\mathrm{m})$ & Area $\left(\mathrm{km}^{2}\right)$ & Elevation $(\mathrm{m})$ & Area $\left(\mathrm{km}^{2}\right)$ \\
\hline 18 & 2040 & 461 & 1145 & 692 & 688 & 949 & 340 & 144 \\
15 & 1952 & 258 & 1070 & 30 & 475 & 2 & 310 & 3 \\
12 & 2120 & 689 & 1145 & 692 & 688 & 949 & 350 & 349 \\
9 & 1978 & 270 & 1100 & 302 & 525 & 252 & 325 & 94 \\
6 & 1949 & 172 & 1075 & 96 & 490 & 4 & 320 & 30 \\
0 & 1958 & 227 & 1097 & 302 & 515 & 225 & 320 & 30 \\
\hline
\end{tabular}

Temperature and rainfall estimates for past 18000 years in

Owens Valley

Z. Yu et al.

Title Page

Abstract

Introduction

Conclusions

References

Tables

Figures

14

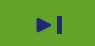

4

Back

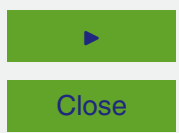

Full Screen / Esc

Printer-friendly Version

Interactive Discussion 


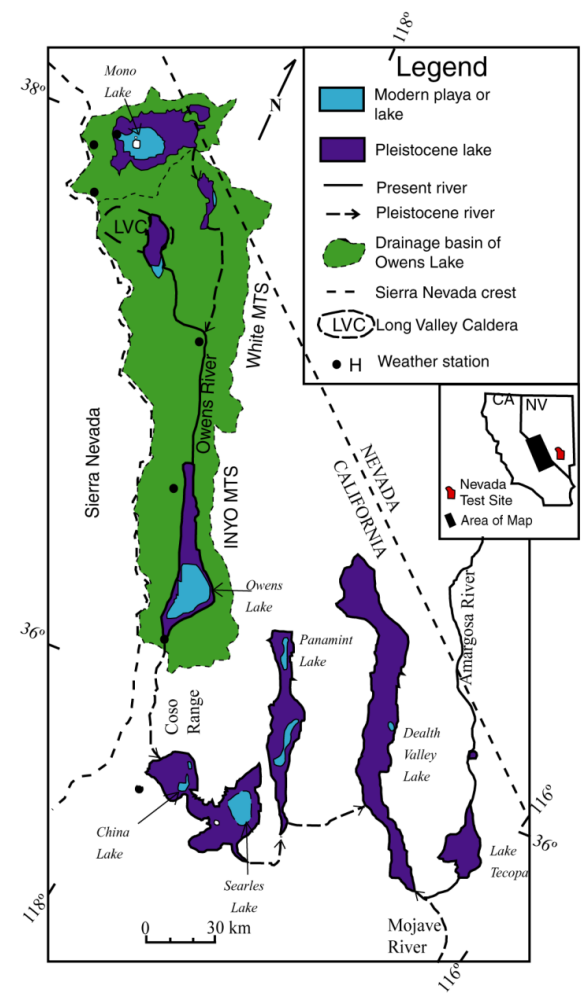

Figure 1. Location map of Owens River system (modified from Smith and Bischoff, 1997).

\section{HESSD}

12, 6505-6539, 2015

Temperature and rainfall estimates for past 18000 years in

Owens Valley

Z. Yu et al.

Title Page

Abstract

Introduction

Conclusions

References

Tables

Figures

14

Back

Close

Printer-friendly Version

Interactive Discussion 


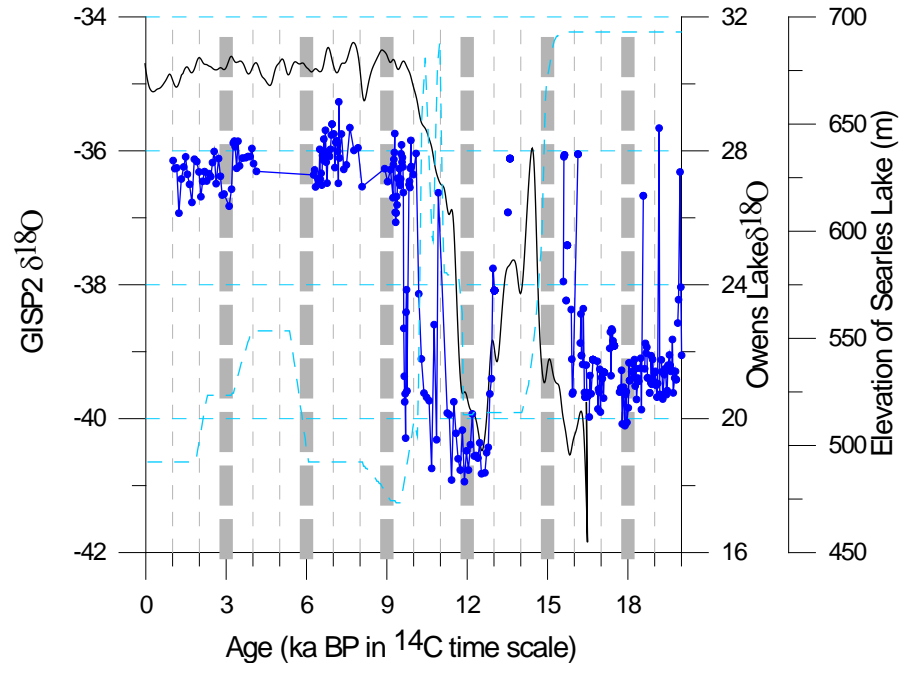

Figure 2. $\delta^{18} \mathrm{O}$ for core OL84B (solid line with dot) (Benson et al., 1997), $\delta^{18} \mathrm{O}$ from GISP2 (solid line) (Stuiver et al., 1995), and elevation of lake surface for Searles Lake (Smith and Street-Perrott, 1983) in the last $20 \mathrm{ka}$.

\section{HESSD}

12, 6505-6539, 2015

Temperature and rainfall estimates for past 18000 years in

Owens Valley

Z. Yu et al.

Title Page

Abstract

Introduction

Conclusions

References

Tables

Figures

14

Back

Close

Printer-friendly Version

Interactive Discussion 


\section{Simulated runoff in Mono Basin}

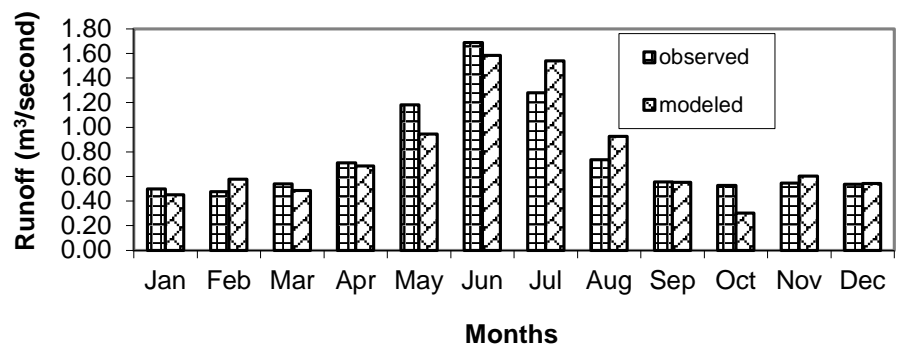

Figure 3. A comparison of observed runoff and simulated runoff in Mono Lake drainage basin.

\section{HESSD}

12, 6505-6539, 2015

Temperature and rainfall estimates for past 18000 years in

Owens Valley

Z. Yu et al.

Title Page

Abstract

Introduction

Conclusions

References

Tables

Figures

14

Back

Close

Printer-friendly Version

Interactive Discussion 


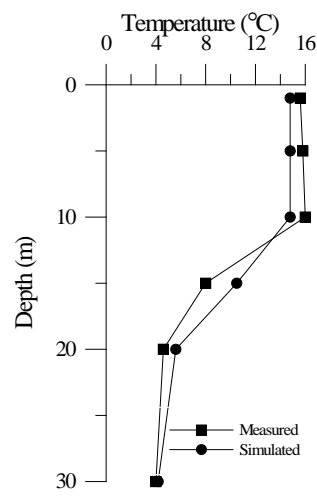

HESSD

12, 6505-6539, 2015

Temperature and rainfall estimates for past 18000 years in

Owens Valley

Z. Yu et al.

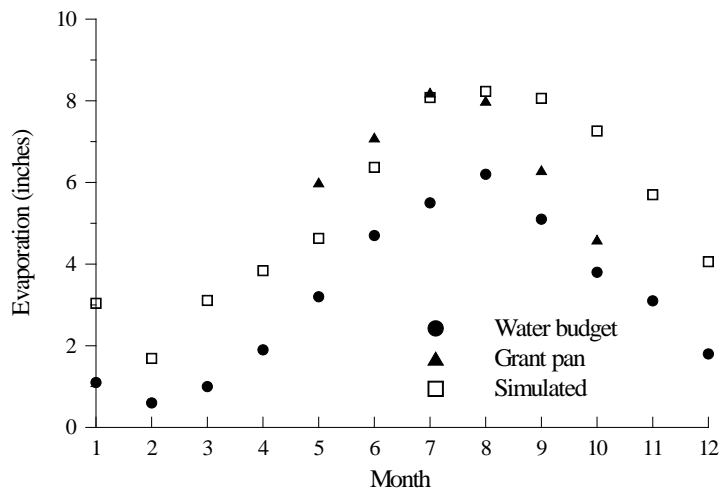

Title Page

Abstract

Introduction

Conclusions

References

Tables

Figures

14
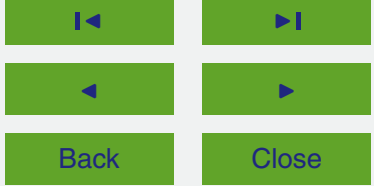

Full Screen / Esc

Figure 4. A plot of simulated and measured temperature profile (Maclntyre et al., 1999) in Mono Lake (upper panel); simulated evaporation and observed evaporation for Mono Lake (lower panel).

Printer-friendly Version

Interactive Discussion 
HESSD

12, 6505-6539, 2015
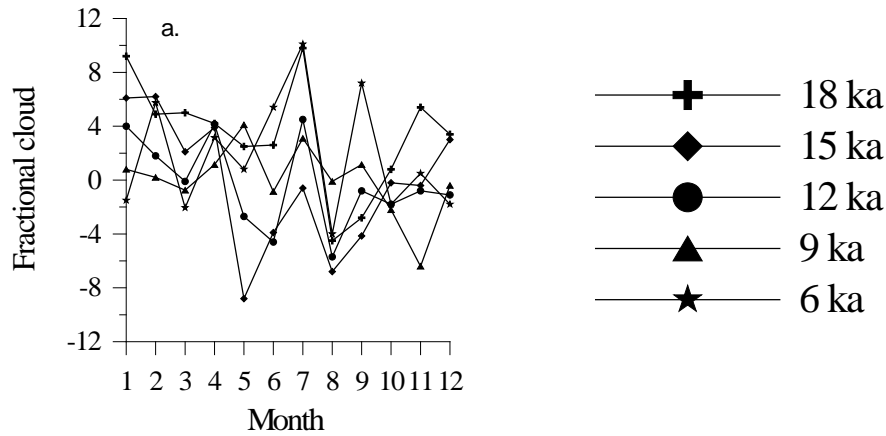

Temperature and rainfall estimates for past 18000 years in

Owens Valley

Z. Yu et al.
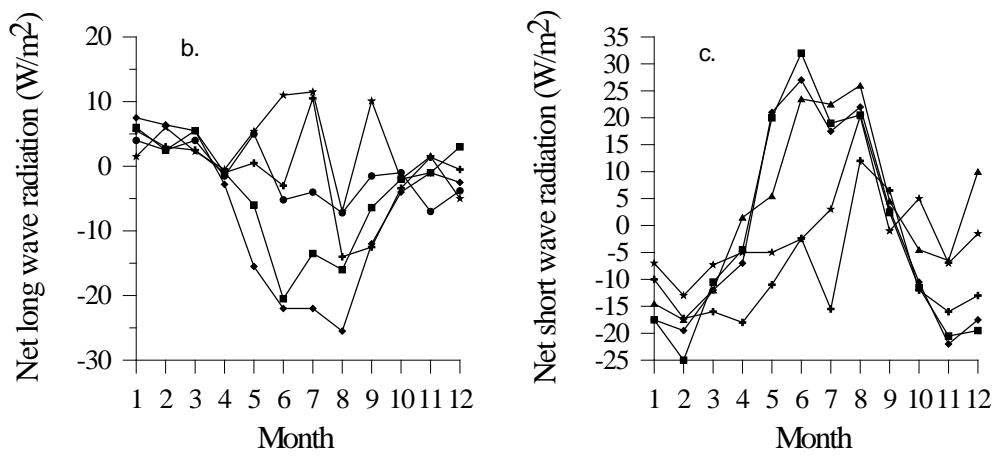

Title Page

Abstract

Introduction

Conclusions

References

Tables

Figures

14

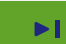

Back

Close

Full Screen / Esc

Figure 5. Inputs of cloud cover and solar radiation for the simulations at 18, 15, 12, 9, and $6 \mathrm{ka}$ (Bartlein et al., 1998). 


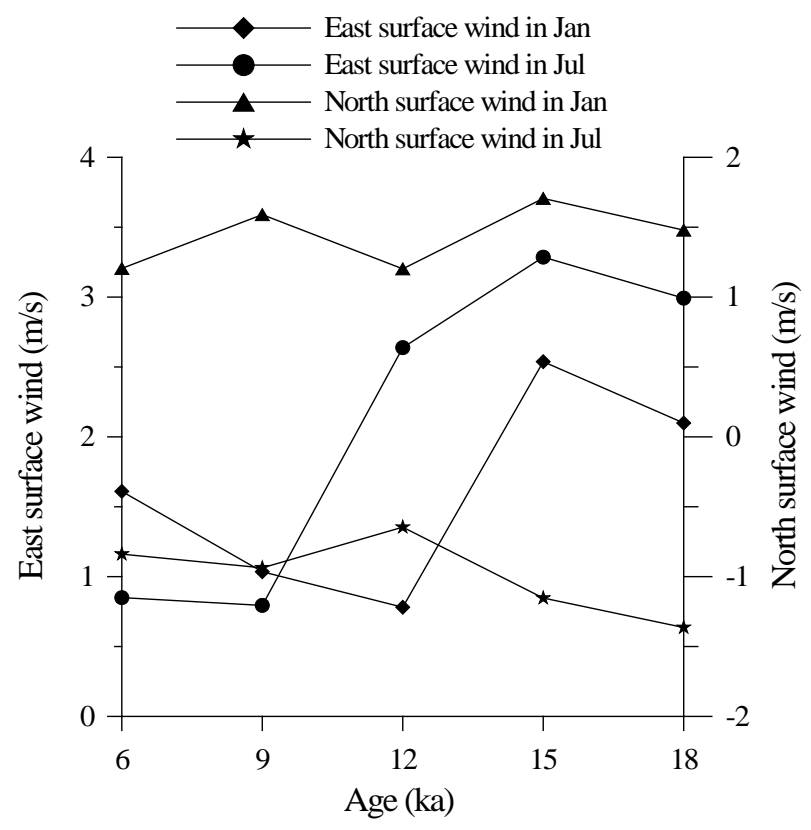

Temperature and rainfall estimates for past 18000 years in

Owens Valley

Z. Yu et al.

Title Page

Abstract

Introduction

Conclusions

References

Tables

Figures

14

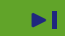

Back

Close

Full Screen / Esc Guetter, 1986).

Printer-friendly Version

Interactive Discussion 

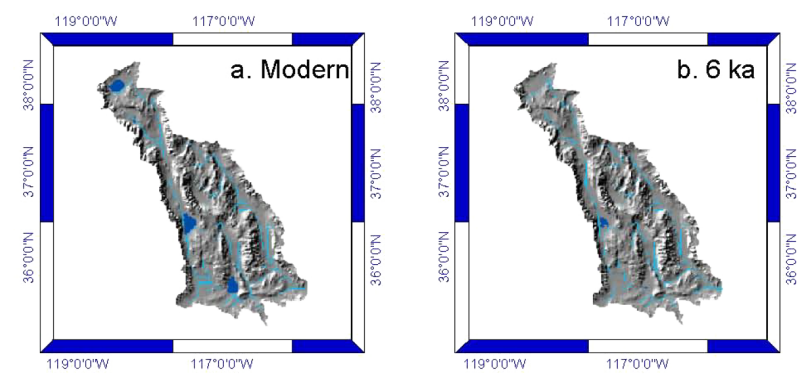

\section{HESSD}

$12,6505-6539,2015$

Temperature and rainfall estimates for past 18000 years in

Owens Valley
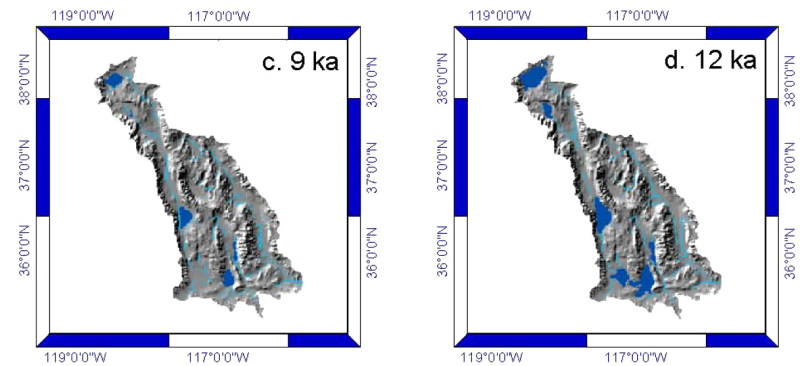

Z. Yu et al.
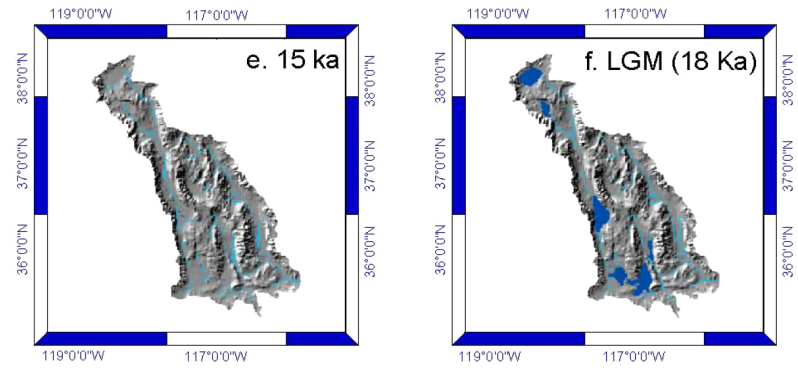

Title Page

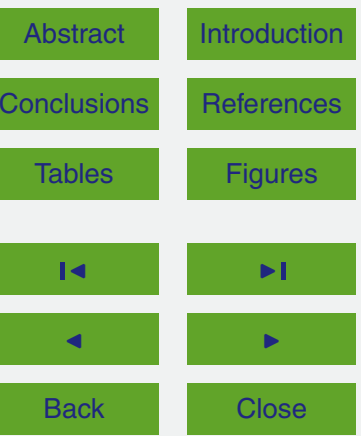

Full Screen / Esc

Figure 7. Simulated lake extents (deep blue) in the last $18 \mathrm{ka}$, and hillshade (gray scale) and stream network (light blue) derived from DEM data.

Printer-friendly Version

Interactive Discussion 

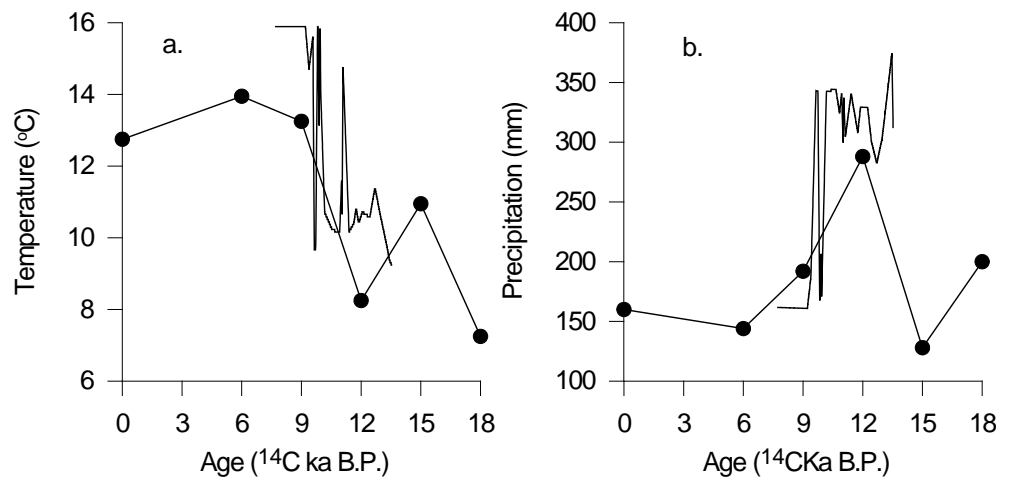

\section{HESSD}

12, 6505-6539, 2015

Temperature and rainfall estimates for past 18000 years in

Owens Valley

Z. Yu et al.

Title Page

Figure 8. Simulated temperature (solid line with dots) and estimated temperature based on pollen (solid line) (Mensing, 2001) in Owens Lake (left panel) and simulated precipitation (solid line with dots) and estimated precipitation based on pollen (solid line) (Mensing, 2001) in Owens Lake (right panel).

14

4

Back

Full Screen / Esc

Printer-friendly Version

Interactive Discussion 